\title{
THE STATE OF COGNITIVE FUNCTIONS AFTER ANGIORECONSTRUCTIVE OPERATIONS ON THE CAROTID ARTERIES
}

\author{
Tanashyan MM¹, Medvedev RB ${ }^{1 凶}$, Lagoda OV ${ }^{1}$, Berdnikovich ES ${ }^{1}$, Skrylev $^{1}{ }^{1}$, Gemdzhian EG ${ }^{2}, \mathrm{Krotenkova} \mathrm{MV}^{1}$ \\ ${ }^{1}$ Research Centre of Neurology, Moscow, Russia \\ ${ }_{2}^{2}$ National Research Center for Hematology, Moscow, Russia
}

\begin{abstract}
Carotid artery stenosis is a risk factor for ischemic stroke. Surgical treatment is often used to improve cerebral perfusion and prevent the development of cerebrovascular pathology and related cognitive impairment. The aim of this prospective pilot study was to evaluate the cognitive functions (CF) of patients after surgery (open or endovascular intervention) on the internal carotid artery. The study included 90 patients (mean age 62 years, $71 \%$ of men) with atherosclerotic lesions of the carotid arteries. The CF was evaluated at four time points (before the intervention, 3, 6, and 9 months after) using cognitive scales and measuring cognitive evoked potentials. The state of the brain substance before and after the intervention was evaluated by the results of diffusion-weighted magnetic resonance imaging (DW-MRI). Three and six months after the operation, the patients demonstrated minor and varied CF alterations by the MMSE scale, but by the end of the observation period ( 9 months) the participants had their CF at the level close to that registered before the operation ( $p=0.43$ ). Thus, the intervention-associated changes in CF, regardless of the surgical approach, were primarily transient in nature. The rare cases of CF deterioration, as registered by the postoperative DW-MRI scans, were linked to the acute brain ischemia, both symptomatic and asymptomatic, and a perioperative stroke (1 case). Advanced age and altered cerebral arteries may be listed as the risk factors for the probable CF deterioration. Evaluation of the connections between CF alterations and multiple cases of intraoperative cerebral vascular embolism requires a longer observation period.
\end{abstract}

Keywords: carotid artery, stenosis, stent, endarterectomy, emboli, cognitive function, analysis of variance

Funding: the study was ordered by the Research Center of Neurology (Federal Research Institution).

Author contribution: Tanashyan MM — study design development, manuscript editing; Medvedev RB — literature analysis, study design development, data collection, analysis and interpretation, manuscript authoring; Lagoda OV and Berdnikovich ES - literature analysis, study design development, data collection and interpretation, manuscript editing; Skrylev SI — angiosurgery, manuscript editing; Gemdzhian EG — study concept and design, data analysis, statistical analysis, manuscript compilation and editing; Krotenkova MV — image data analysis and interpretation, manuscript editing.

Compliance with ethical standards: the study was approved by the Research Center of Neurology Ethics Committee (protocol № 11/14 of November 19, 2014). All patients or their legally authorized representatives have signed the informed consent for surgery; the study followed the ethical principles of the Declaration of Helsinki (1975).

$\triangle$ Correspondence should be addressed: Roman B. Medvedev

Volokolamskoye shosse, 80, Moscow, 125367; medvedev-roman@yandex.ru

Received: 15.08.2019 Accepted: 29.08.2019 Published online: 16.09.2019

DOI: $10.24075 /$ brsmu.2019.059

\section{СОСТОЯНИЕ КОГНИТИВНЫХ ФУНКЦИЙ ПОСЛЕ АНГИОРЕКОНСТРУКТИВНЫХ ОПЕРАЦИЙ НА СОННЫХ АРТЕРИЯХ}

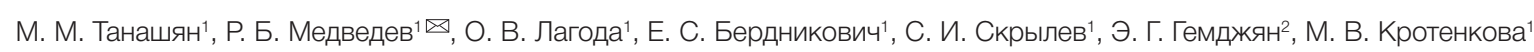

${ }^{1}$ Научный центр неврологии, Москва, Россия

2 Национальный медицинский исследовательский центр гематологии, Москва, Россия

\begin{abstract}
Атеросклероз сонных артерий является фактором риска ишемического инсульта. Для улучшения мозговой перфузии и предотвращения развития цереброваскулярной патологии и связанных с ней когнитивных нарушений нередко используют хирургическое лечение. Целью данного проспективного поискового исследования было оценить когнитивные функции (КФ) пациентов после операции (открытого или эндоваскулярного вмешательства) на внутренней сонной артерии. В исследование было включено 90 пациентов (средний возраст - 62 года, $71 \%$ мужчин) с атеросклеротическим поражением сонных артерий. КФ оценивали в четырех временных точках (до вмешательства, через 3, 6 и 9 месяцев после него) с использованием когнитивных шкал и измерением когнитивных вызванных потенциалов. Состояние вещества головного мозга до и после вмешательства оценивали по результатам диффузионно-взвешенной магнитно-резонансной томографии (ДВ-МРТ). Через 3 и 6 месяцев после операции у пациентов наблюдали небольшие разнонаправленные изменения КФ (по шкале MMSE), но к концу срока наблюдения (9 месяцам) распределение оценок КФ у пациентов приблизилось к дооперационному ( $p=0,43)$. Таким образом, ассоциированные с вмешательством (независимо от его вида) изменения КФ носили преимущественно транзиторный характер. Единичные случаи ухудшения (по данным ДВ-МРТ после операции) КФ были ассоциированы с острыми очагами ишемии (как симптомными, так и бессимптомными) в веществе мозга, а также с периоперационным инсультом (1 случай). К факторам риска неблагоприятного прогноза для КФ можно отнести: пожилой возраст и изменения в церебральных артериях. Для оценки связи КФ с множественными интраоперационными эмболиями сосудов мозга требуется более длительное наблюдение.
\end{abstract}

Ключевые слова: сонная артерия, стеноз, стент, эндартерэктомия, эмболия, когнитивные функции, дисперсионный анализ

Финансирование: работа выполнена в рамках государственного задания ФГБНУ НЦН.

Информация о вкладе авторов: М. М. Танашян - разработка дизайна исследования, редактирование рукописи; Р. Б. Медведев - анализ литературы, разработка дизайна исследования, сбор, анализ и интерпретация данных, написание рукописи; О. В. Лагода и Е. С. Бердникович - анализ литературы, разработка дизайна исследования, сбор и интерпретация данных, редактирование рукописи; С. И. Скрылев - проведение ангиохирургических операций, редактирование рукописи; Э. Г. Гемджян - концепция и дизайн исследования, анализ данных, статистический анализ, составление и редактирование рукописи; М. В. Кротенкова - анализ и интерпретация данных изображения, редактирование рукописи.

Соблюдение этических стандартов: исследование одобрено этическим комитетом Научного центра неврологии (протокол № 11/14 от 19 ноября 2014 г.). Все пациенты (или их законно уполномоченные представители) подписали добровольное информированное согласие на проведение оперативного лечения; исследование проведено в соответствии с этическими принципами Хельсинкской декларации 1975 г.

$\bowtie$ Для корреспонденции: Роман Борисович Медведев Волоколамское шоссе, д. 80, г. Москва, 125367; medvedev-roman@yandex.ru

Статья получена: 15.08.2019 Статья принята к печати: 29.08.2019 Опубликована онлайн: 16.09.2019

DOI: 10.24075/vrgmu.2019.059 
Vascular diseases are some of the leading causes of mortality and permanent disability, which makes their prevention and treatment an extremely urgent task from both medical and social viewpoints [1]. Average life expectancy is growing, as does the number of diagnosed vascular diseases and cognitive disorders associated with them. These factors call for further investigation of cerebrovascular pathology.

Cognitive dysfunction hinders social adaptation of the patients. It degrades their quality of life and, moreover, does the same to their ability to control the core disease and its comorbidities: arterial hypertension, atherosclerosis, diabetes mellitus.

The most important cause of the ischemic stroke is atherosclerotic stenosis of brachiocephalic arteries (BCA) and the internal carotid artery (ICA) in particular. The atherothrombotic subtype cerebral circulation failures cause over $30 \%$ of ischemic strokes, and up to $80 \%$ of them occur in the absence of preceding symptoms, which underlines the importance of thorough examination of atherosclerosis patients.

Embolism and cerebral hypoperfusion are the two major mechanisms distinguished in the pathogenesis of cognitive impairment $(\mathrm{Cl})$ associated with an ICA atherosclerosis [2]. Regardless of the presence or absence of signs of white matter lesions on the MRI scans, ICA stenosis is an independent marker of $\mathrm{Cl}$. A study that recruited over 4000 patients with asymptomatic ICA stenosis revealed $\mathrm{Cl}$ in the group that had the disease in the pronounced form [3]. There is evidence of direct correlation between ICA intima-media thickness, which is the earliest atherosclerosis marker, and lower neuropsychological testing scores [4].

The current medical care doctrine prescribes shifting the focus from disease treatment to active health preservation pursued by each individual. In this context, guaranteeing adequate perfusion of the brain is the key preventive measure against development of a cerebrovascular pathology and $\mathrm{Cl}$.

Alongside antithrombotic therapy, surgery offers effective ways to normalize cerebral circulation. The methods are carotid endarterectomy (CEE) and transluminal balloon angioplasty with carotid artery stenting (CAS) [5-8]. Vascular bed correction undoubtedly improves cerebral circulation on the whole; however, with accumulation of practical clinical experience, some drawbacks peculiar to the surgery techniques were revealed. One of such drawbacks is the risk of intraoperative embolism and hemodynamic instability (up to a stagnation) and subsequent development of cerebral ischemia [9]. According to a randomized CREST study, the incidence of perioperative stroke after CEE and CAS was 2.3 and $4.1 \%$, respectively [10]. DW-MRI scans reveal acute ischemia foci (AIF) in $21 \%$ of patients that underwent open surgery and $50 \%$ of those who had an endovascular intervention [11].

What links carotid revascularization and cognitive functions (CF) is still not entirely clear due to the large number of factors: 1) patients heterogeneity in stenosis clinical manifestations, localization and severity, initial status of cerebral perfusion, time between appearance of the symptoms and revascularization [12]; 2) types of neuropsychological tests used and timing of such assessments; 3) variability of surgical techniques and postoperative changes classification criteria [13]. In this study we aimed to identify and evaluate cognitive changes in surgery patients that had their ICA atherosclerosis operated on.

\section{METHODS}

The study included 90 patients (64 male and 26 female, age 47-83 years, average age 61 years) who were observed at the Department of General Angioneurology of the Research Center of Neurology (Moscow). The inclusion criteria were: any gender; an active chronic ischemic cerebrovascular disease (discirculatory encephalopathy, stage 1 or 2); ICA surgery performed from May 2015 to December 2018 at the Department of Vascular and Endovascular Surgery (27 patients underwent carotid endarterectomy (CEE), 63 patients underwent carotid angioplasty with stenting). The exclusion criteria were: a pronounced cardiac and somatic pathology; severe stroke; mental disorders; hemianopsia as a result of posterior cerebral artery circulation disorders; pronounced $\mathrm{Cl}$ (MMSE score < 24 points) making neuropsychological testing impossible.

The carotid artery atherosclerosis diagnosis was confirmed with the help of the Viamo ultrasound examination system (Toshiba; Japan); we applied the NASCET (North American Symptomatic Carotid Endarterectomy Trial) examination algorithm [14].

All patients had their cognitive status assessed before surgery and 3, 6, and 9 months afterwards. We used the following CF assessment tools and methods: MMSE (MiniMental State Examination) [15]; 10 word memory trial, frontal assessment battery (FAB), clock-drawing test, digit span test (subtest of Wechsler Adult Intelligence Scale and Wechsler Memory Scales), conceptualization test, Schulte table and dynamic praxis [16]. The CF assessment tools and methods were selected based on their functional compatibility with the cognitive evoked potentials (CEP) examination.

We used the Neuro-MVP (Neurosoft; Russia) device and relied on the P300 wave to examine CEP; the results of the examination allowed objectification of changes in the participants' CF. 25 healthy individuals of the appropriate age provided baseline P300 potential data. We measured the P300 amplitude from the previous negative peak to the P300 peak.

Considering selection of the surgical treatment method, patients that had CEE contraindications according to the SAPPHIRE (Stenting and Angioplasty With Protection in Patients at High Risk for Endarterectomy) [17] trial results and CAS indications according to the CREST [10] trial underwent endovascular surgery. Twenty-four hours after open or endovascular surgery, we initiated neurological examination that implied deficit assessment using the National Institutes of Health $(\mathrm{NIH})$ stroke scale [18].

DW-MRI scans were used to evaluate the condition of the brain substance before and 24 hours after the intervention. We used a Siemens Magnetom Symphony 1.5T MRI system (1.5 Tesla magnet) to obtain the scans. The foci were predominantly small, therefore we relied on the diffusion-weighted scan images (b1000 diffusion coefficient) to assess damage to the brain substance [19].

At least 5 days before the surgery all patients received corrective antithrombotic, hypolipidemic, antihypertensive and antianginal therapy. After the surgery, all patients received basic drug therapy (antithrombotic, antihypertensive and lipidlowering drugs). No nootropic drugs were prescribed.

Statistical analysis was performed using repeated measures ANOVA and analysis of contingency tables.

\section{RESULTS}

All patients participating in the study were diagnosed with arterial hypertension; every second patient exhibited two or more risk factors for vascular diseases. Sixty (67\%) patients had cerebral circulation disturbances (ischemic) registered in their medical histories. Having analyzed the initial data, we 
learned that $33 \%$ of the patients scored $28-30$ points on the MMSE scale, which indicates normal cognition, and 67\% scored 25-27 points, which signals of mild $\mathrm{Cl}$. Analysis of the CF dynamics (MMSE scale) 3, 6 and 9 months after surgery revealed no notable deterioration: at 3 and 6 months, we detected multidirectional changes in CF (greater variety of scores, isolated cases of pronounced CF alterations), but at the 9-month time point, when the observation period ended, the said changes practically disappeared and all patients scored close to the pre-surgery values, the difference between preand post-surgery scores being insignificant $(p=0.43)$ (Fig. 1, 2). Thus, the post-surgery CF changes registered were primarily transient in nature.

Additional neuropsychological testing revealed baseline moderate impairments of verbal thinking, attention and shortterm memory in some patients (Table 1). The development of $\mathrm{Cl}$ was associated with the severity of BCA atherosclerosis, advanced age, arterial hypertension, coronary heart disease, diabetes mellitus, previous cerebral circulation failures.

Thorough post-surgery examination of these patients revealed a perioperative stroke (embolism of the middle cerebral artery) on the intervention side in one patient: the neurological deficit reached 6 points on the $\mathrm{NIH}$ stroke scale; the stroke manifested itself in the form of motor disorders. Further observation of this patient and verbal thinking and speech fluency tests revealed semantic memory deterioration that persisted throughout the study.
Positive changes were mainly observed in such neurodynamic processes as attention, fluency, operative and short-term memory (Fig. 3).

We found no correlation between the type of surgery performed and CF scores of the examined patients. Throughout the entire observation period, some patients older than 60 years exhibited more pronounced $\mathrm{Cl}$. Most patients younger than 60 years (86\%) had their CF changing positively (MMSE scores) by the 6th month of the observation; by the 9-month time point, we registered a growing share of patients whose attention and short-term scores returned to norm, which was further confirmed by the P300 peak amplitude changes ( $p=0.05$ ). Previous ischemic strokes had no detectable effect on the post-surgery CF alterations.

The analysis of DW-MRI scans taken shortly after surgery revealed asymptomatic AIF embolic origin visualizing in 30 (33\%) patients. The detected brain substance alterations were predominantly localized in the cortex (16 (53\%)) on the intervention side (22 (73\%)); the spots measured up to $5 \mathrm{~mm}$. A separate analysis of DW-MRI scans and CEP data showed that the positive dynamics registered in patients without AIF at the 3- and 6-month time points and lack of such in patients with AlF allow considering the foci a factor preventing CF restoration post-surgery (Fig. 4).

Neuropsychological tests have also detected minor positive changes in the CF of patients without AIF 3, 6 and 9 months post-surgery.

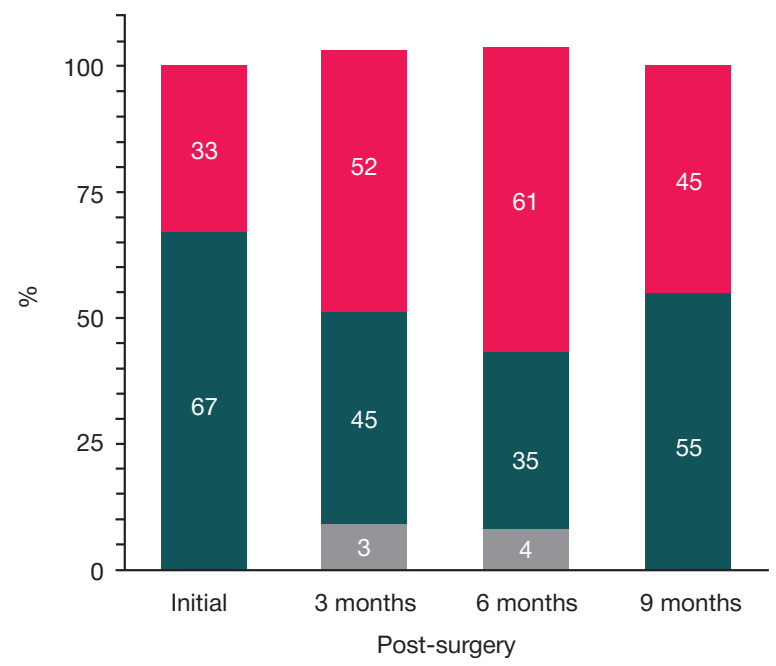

Fig. 1. Dynamics of the proportion of patients ( $Y$ axis, \%) with different MMSE scores: no cognitive impairment (28-30 score) — upper fields, mild impairment (25-27 score) - middle fields, severe impairment $(<25$ score $)$ - two lower fields

Table 1. Patient CF assessment scores (based on screening tests)*

\begin{tabular}{|c|c|c|c|c|}
\hline \multirow{2}{*}{ Neuropsychological tests } & \multicolumn{4}{|c|}{ Screening tests } \\
\hline & Before treatment & After 3 months & After 6 months & After 9 months \\
\hline MMSE & $27.1 \pm 0.2$ & $28.3 \pm 0.1$ & $28.2 \pm 0.1$ & $27.2 \pm 0.1$ \\
\hline FAB & $13.1 \pm 0.3$ & $17.4 \pm 0.1$ & $18.1 \pm 0.2$ & $18.7 \pm 0.3$ \\
\hline Schulte table & $57.3 \pm 8.5$ & $53.4 \pm 13.1$ & $47.7 \pm 9.6$ & $46.2 \pm 10.3$ \\
\hline Digit span test (direct) & $5.1 \pm 1.1$ & $5.9 \pm 1.1$ & $6.1 \pm 1.1$ & $6.5 \pm 1.2$ \\
\hline Digit span test (reverse) & $2.5 \pm 1.1$ & $3.7 \pm 1.0$ & $3.8 \pm 1.1$ & $3.8 \pm 1.1$ \\
\hline Dynamic praxis & $1.6 \pm 0.6$ & $2.1 \pm 0.7$ & $2.2 \pm 0.8$ & $2.3 \pm 0.6$ \\
\hline Clock-drawing test & $4.6 \pm 2.2$ & $5.7 \pm 0.2$ & $5.9 \pm 1.1$ & $5.8 \pm 1.0$ \\
\hline Conceptualization & $2.3 \pm 0.7$ & $2.3 \pm 0.1$ & $2.2 \pm 0.4$ & $2.3 \pm 0.3$ \\
\hline
\end{tabular}

Note: * — test results are presented as mean values with standard errors of mean (test result histograms are close to normal distribution). 


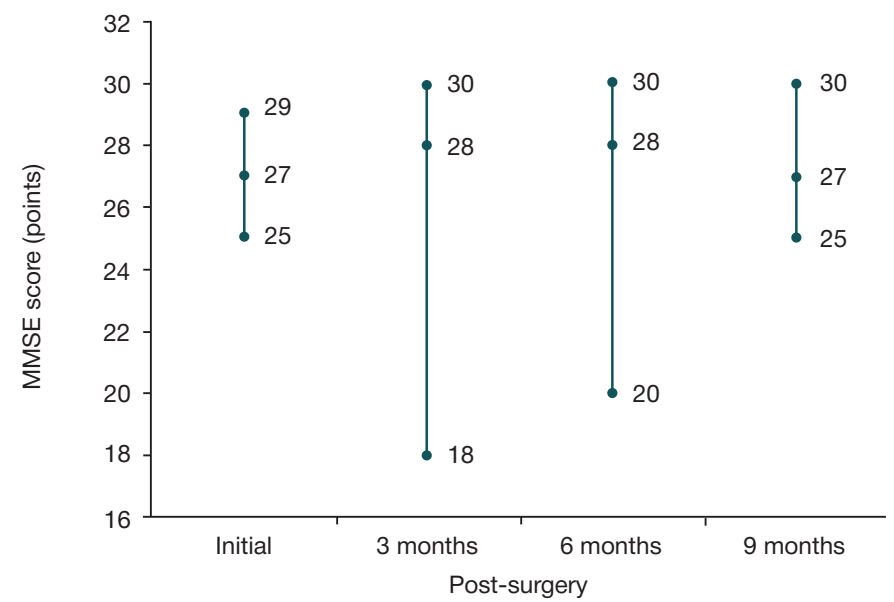

Fig. 2. Dynamics of MMSE scores describing cognitive functions (pre- and post-surgery at different time points); mean values (with minimum and maximum) are presented

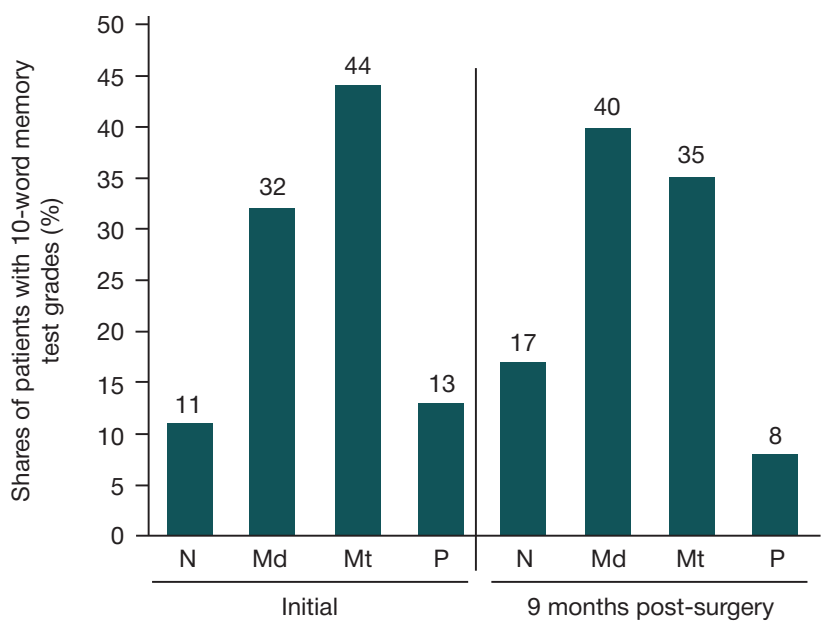

Fig. 3. Operative memory scores (10-word test) compared, pre-surgery (initial) and post-surgery (by the end of the observation period); $\mathrm{N}-$ norm (10 words): $\mathrm{Md}$ - mild impairments (8-9); Mt — moderate (6-7); S — severe (<6). By the end of the observation period (9 months) all patients generally exhibited improvements of their operative memory

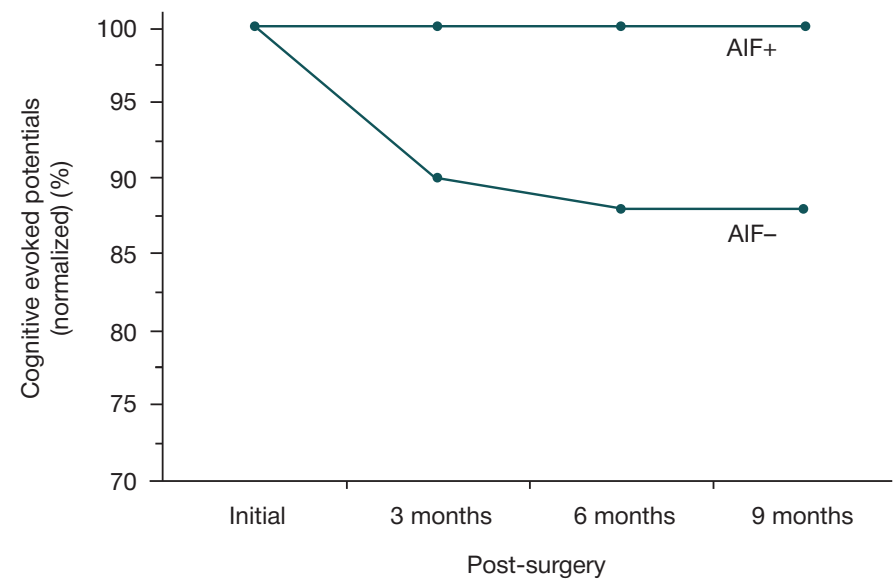

Fig. 4. CEP dynamics in patients with intraoperative acute ischemia foci (AIF+) and in patients without intraoperative acute ischemia foci (AIF-): during the observation period, the CEP level in the AIF+ group $(n=30)$ did not change, but in the AIF-group $(n=60)$ it decreased by $15 \%(p=0.05)$. Normalized (divided by the initial levels) main CEP values (\%) are given

There were no independent and significant predictors registered that were associated with the patient's condition 9 months after surgery.

The results of the P300 CEP study acquire particular importance in the context of studying CF. Initial testing of 90 patients showed that 22 (25\%) of them had no changes in the features considered, while $68(75 \%)$ patients exhibited the following deviations from the norm: 24 had no P300 peak, 25 had the peak latent, 19 had the P300 amplitude reduced. It should be noted here that the features of P300 (we give average values with standard deviations) registered in patients with arterial hypertension and without it were not significantly different from each other: $366.4 \pm 29.6$ versus $360.9 \pm 51.1 \mathrm{~ms}$ (latency) and $5.4 \pm 2.6$ versus $5.4 \pm 3.2 \mu \mathrm{V}$ (amplitude). The P300 features revealed neither hemispheric asymmetry nor a correlation with the number of affected extracranial arteries (from one to four).

In the postoperative period, the average P300 latency and amplitude did not differ from the initial values. In the longer 


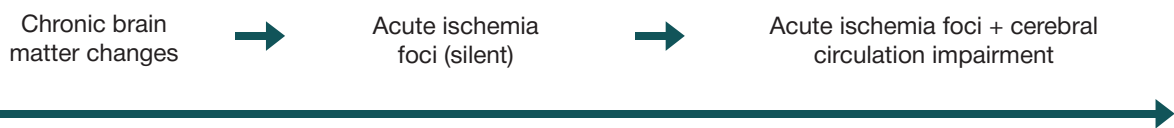

Fig. 5. Possible changes in the brain matter and post-surgery cognitive functions deterioration vector

term (9 months), P300 peak latency decrease and a slight response amplitude increase were registered in 55 (61\%) patients. The average P300 potential latency values (with standard deviations) pre-surgery were $364.5 \pm 37.5 \mathrm{~ms}$ response amplitude $-5.4 \pm 2.7 \mu \mathrm{V}$; post-surgery, the values were $349.5 \pm 42.7 \mathrm{~ms}$ and $6.4 \pm 3.3 \mu \mathrm{V}$, respectively.

\section{DISCUSSION}

The internal carotid artery system supplies about $2 / 3$ of all the blood delivered to the namesake brain hemisphere. Atherosclerotic lesions in the extracranial arteries significantly hinder cerebral blood flow. The hemodynamic effect ICA stenosis has on cerebral circulation can lead to the development of a stroke with a clear neurological deficit or brain substance diffusion manifested in the form of diffused neurological symptoms. Post-surgery CF changes have been of interest to researchers for some time now. One of the early studies dedicated to psychopathological disorders following cardiac surgery reports the participants' impaired ability to focus attention, impaired delayed and fast memory, slowed psychomotor processes. The authors of this study concluded that it is advanced age and hypertension that are the risk factors for the development of postoperative cognitive complications [20].

The first research reports covering $\mathrm{Cl}$ after carotid artery surgery were published in mid-1990s. The degree of intraoperative ischemia was assessed by monitoring somatosensory cortical evoked potentials during surgery. The alterations of neuropsychological indicators that depended on the degree of intraoperative ischemia were detected in patients that survived a stroke previously and had a more pronounced degree of damage to the arteries [21].

Further research efforts addressed the link between the stage of carotid stenosis and $\mathrm{Cl}$ in patients showing no clinical signs of dementia. It was shown that CF deteriorate in patients that do not suffer from dementia but have stenosis at an advanced stage, while at the initial stages the disease does not affect the said functions. According to the psychometric tests, the revealed mild $\mathrm{Cl}$ correlated with a change in latency of the P300 potential. The altered P300 potentials associated with mild CI were found in ICA stenosis patients, both asymptomatic and exhibiting symptoms locally [22]. In contrast to psychometric tests, CEP do not depend on the patient's motivation.

Given that the results of some studies indicate a significant improvement in CF after carotid artery interventions [23] while other papers provide evidence to the contrary [24, 25], the issue of identifying the factors driving change in cognitive abilities following surgery remains open.

We also studied CF after ICA surgery; in our work, we learned that the MMSE scores describing the state of CF in patients were most varied in the first 3 months post-surgery, which may have been a result of the patients' psychoemotional reaction to the operation [26]. The changes were mainly observed in such neurodynamic processes as attention, fluency, operative and short-term memory. After 9 months, CF have on average returned to the initial (pre-surgery) level. We can make an assumption that the long-term factors affecting the CF post-surgery are the initial status of the said functions and the adequacy of the secondary prevention measures aimed at vascular diseases. In addition, it is probable that restoration of perfusion and improvement of brain metabolism also cause a gradual recovery from the $\mathrm{Cl}[27,28]$.

The lack of connection between CF and the type of surgery performed (CEE or CAS) we have registered in our study is consistent with the findings reported by other researchers [29, 30].

At the 6-month time point, we detected a link between the patient's age (below 60 years) and the positive dynamics in CF restoration; moreover, at the 9-month time point we witnessed a growing number of patients whose short-term memory and attention indicators returned to norm, a finding consistent with other such findings published earlier [31, 32].

A feature of our work was the comparison of changes in the brain substance (as seen on DW-MRI scan) with the CF status at various time points post-surgery. We have detected some form of AIF in 33\% of patients shortly after surgery. However, there was only one case of an acute ischemic stroke with hemiparesis on the contralateral side; the remaining AIF cases diagnosed were clinically asymptomatic.

Only a few studies [33, 34] did the DW-MRI-assisted correlation of acute ischemic lesions and neuropsychological outcome parameters, which is why there is still insufficient data to enable assessment of the forecast effect of detected lesions on cognitive status.

The clinical neuroimaging, neuropsychological and neurophysiological study we conducted allowed formulating a single CF component and establishing that the presence of AIF worsens the prognosis for cognitive functions. The dynamics of this single combined measure of CF in the remaining periods of observation depends on their clinical manifestations. In this connection, it is possible to suggest CF deterioration after CA stenosis surgery (Fig. 5).

The limitation of this study is the relatively short observation period (9 months). Continuation of the study would allow verifying the results.

\section{CONCLUSIONS}

1. One of the most important symptoms of chronic cerebrovascular disease in most patients with atherosclerotic pathology of the carotid arteries is cognitive dysfunction, which requires mandatory neuropsychological, neuroimaging and neurophysiological testing when planning angioreconstructive surgery. 2. Cognitive impairments in patients after angioreconstructive surgery on carotid artery are associated with the possible changes (symptomatic or asymptomatic) in the state of the brain substance. 
1. Tanashyan MM, Medvedev RB, Evdokimenko AN, Gemdzhian EG, Skrylev SI, Lagoda OV, et al. Prediction of ischaemic lesions of the brain in reconstructive operations on internal carotid arteries. Angiol Sosud Khir. 2017; 23 (1): 59-65.

2. Bossema ER, Brand N, Moll FL, Ackerstaff RG, de Haan EH, van Doornen LJ. Cognitive functions in carotid artery disease before endarterectomy. J Clin Exp Neuropsychol. 2006; (28): 357-69.

3. Johnston SC, O'Meara ES, Manolio TA, Lefkowitz D, O'Leary DH, Goldstein S, et al. Cognitive impairment and decline are associated with carotid artery disease in patients without clinically evident cerebrovascular disease. Ann Intern Med. 2004; 140 (4): 237-47.

4. Romero JR, Beiser A, Seshadri S, Benjamin EJ, Polak JF, Vasan RS, et al. Carotid artery atherosclerosis, MRI indices of brain ischemia, aging, and cognitive impairment: the Framingham study. Stroke. 2009; 40 (5): 1590-6.

5. Kuntsevich GI, Tanashyan MM, Skrylev SI, Krotenkova MV, Shchipakin VL, Koshcheev Alu, et al. Intraoperative monitoring of cerebral blood-flow and condition of cerebral at open and endovascular interventions in carotid system. Angiol Sosud Khir. 2011; 17 (3): 43-8.

6. Barnett HJM, Taylor DW, Haynes RB, Sackett DL, Peerless SJ, Ferguson GG, et al. North American Symptomatic Carotid Endarterectomy Trial Collaborators. Beneficial effect of carotid endarterectomy in symptomatic patients with high grade carotid stenosis. N Engl J Med. 1991; 325 (7): 445-53.

7. Endarterectomy for asymptomatic carotid artery stenosis. Executive Committee for the Asymptomatic Carotid Atherosclerosis Study. JAMA. 1995; 273 (18): 1421.

8. Endovascular versus surgical treatment in patients with carotid stenosis in the Carotid and Vertebral Artery Transluminal Angioplasty Study (CAVATAS): a randomised trial. Lancet. 2001; 357 (9270): 1729-37.

9. Mas JL, Trinquart L, Leys D, Albucher JF, Rousseau H, Viguier A, et al. Endarterectomy Versus Angioplasty in Patients with Symptomatic Severe Carotid Stenosis (EVA-3S) trial: results up to 4 years from a randomised, multicentre trial. Lancet Neurol. 2008; 7 (10): 885-92.

10. Brott TG, Hobson RW, Howard G, Roubin GS, Clark WM, Brooks W, et al. Stenting versus endarterectomy for treatment of carotid-artery stenosis. N Engl J Med. 2010; 363 (1): 11-23.

11. Medvedev RB, Tanashyan MM, Skrylev SI, Gemdzhian EG, Gulevskaya TS, Anufriev PL. Relation between ultrasonographic and morphological characteristics of atherosclerotic plaques of carotid sinus. Angiol Sosud Khir. 2018; 24 (4): 43-9.

12. Altinbas $A$, van Zandvoort MJ, van den Berg E, Jongen LM, Algra $A$, Moll FL, et al. Cognition after carotid endarterectomy or stenting a randomized comparison. Neurology. 2011; 77 (11): 1084-90.

13. Zhou W, Hitchner E, Gillis K, Sun L, Floyd R, Lane B, et al. Prospective neurocognitive evaluation of patients undergoing carotid interventions. J Vasc Surg. 2012; 56 (6): 1571-8.

14. Barnett HJ, Taylor DW, Eliasziw M, Fox AJ, Ferguson GG, Haynes RB, et al. Benefit of carotid endarterectomy in patients with symptomatic moderate or severe stenosis. North American Symptomatic Carotid Endarterectomy Trial Collaborators. N Engl J Med. 1998; 339 (20): 1415-25.

15. Folstein MF, Folstein SE, McHugh PR. "Mini-mental state". A practical method for grading the cognitive state of patients for the clinician. J Psychiatr Res. 1975; 12 (3): 189-98.

16. Yakhno NN. Cognitive impairment in neurological practice. Nevrologicheskii Zhurnal. 2006; 11 (1): 4-12.

17. Yadav JS, Wholey MH, Kuntz RE, Fayad P, Katzen BT, Mishkel GJ, et al. Protected carotid-artery stenting versus endarterectomy in high-risk patients. N Engl J Med. 2004; 351 (15): 1493-501.

18. Brott T, Adams HP Jr, Olinger CP, Marler JR, Barsan WG, Biller J, et al. Measurements of acute cerebral infarction: a clinical examination scale. Stroke. 1989; 20 (7): 864-70.
19. Medvedev RB, Tanashian MM, Kuntsevich Gl, Lagoda OV, Skrylev SI, Krotenkova MV, et al. Ischaemic lesions of cerebral after carotid stenting. Angiol Sosud Khir. 2015; 21 (1): 65-71.

20. Fox HM, Rizzo ND, Gifford S. Psychological observations of patients undergoing mitral surgery; a study of stress. Psychosom Med. 1954; 16 (3): 186-208.

21. Kügler CF, Vlajic $P, F u n k H$, Raithel D, Platt D, et al. The event-related P300 potential approach to cognitive functions of nondemented patients with cerebral and peripheral arteriosclerosis. J Am Geriatr Soc. 1995; 43 (11): 1228-36.

22. Inoue T, Ohwaki K, Tamura A, Tsutsumi K, Saito I, Saito N. Subclinical ischemia verified by somatosensory evoked potential amplitude reduction during carotid endarterectomy: negative effects on cognitive performance clinical article. J Neurosurg. 2013; 118 (5): 1023-9.

23. Xu G, Liu X, Meyer JS, Yin Q, Zhang R. Cognitive performance after carotid angioplasty and stenting with brain protection devices. Neurol Res. 2007; (29): 251-55.

24. Witt K, Borsch K, Daniels C, Walluscheck K, Alfke K Neuropsychological consequences of endarterectomy and endovascular angioplasty with stent placement for treatment of symptomatic carotid stenosis: a prospective randomised study. $J$ Neurol. 2007; (254): 1524-32.

25. Lal BK, Younes M, Cruz G, Kapadia I, Jamil Z, Pappas PJ. Cognitive changes after surgery vs stenting for carotid artery stenosis. J Vasc Surg. 2011; 54 (3): 691-8.

26. Vybornykh DE, Fedorova SYu, Khrushchev SO, Drokov MYu, Gemdzhian EG, Kuzmina LA, Parovichnikova EN. Cognitive impairments in patients with hematological malignancies prior and after allogeneic hematopoietic stem cells transplantation. Obozrenie psihiatrii i medicinskoj psihologii im VM Behtereva. 2019; (2): 18-26.

27. Shimada Y, Kobayashi M, Yoshida K, Terasaki K, Fujiwara S, Kubo Y, et al. Reduced Hypoxic Tissue and Cognitive Improvement after Revascularization Surgery for Chronic Cerebral Ischemia. Cerebrovasc Dis. 2019; 47 (1-2): 57-64.

28. List J, Hertel-Zens S, Kübke JC, Lesemann A, Schreiber SJ, Flöel A. Cortical reorganization due to impaired cerebral autoregulation in individuals with occlusive processes of the internal carotid artery. Brain Stimul. 2014; 7 (3): 381-7.

29. Kuo-Lun Huang, Ting-Yu Chang, Meng-Yang Ho, Wei-Hao Chen, Mei-Yu Yeh, Yeu-JhyChang, et al. The correlation of asymmetrical functional connectivity with cognition and reperfusion in carotid stenosis patients. Neuro Image Clinical. 2018; (20): 476-84.

30. Crawley F, Stygall J, Lunn S, Harrison M, Brown MM. Comparison of microembolism detected by transcranial Doppler and neuropsychological sequelae of carotid surgery and percutaneous transluminal angioplasty. Stroke. 2000; (31): 1329-34.

31. Ortega G, Alvarez B, Quintana M, Yugueros X, Alvarez-Sabin J, Matas M. Asymptomatic carotid stenosis and cognitive improvement using transcervical stenting with protective flow reversal technique. Eur J Vasc Endovasc Surg. 2014; 47 (6): 585-92.

32. Turan TN, Smock A, Cotsonis G, Bachman D, Al Kasab S, Lynn MJ, et al. SAMMPRIS Investigators. Is There Benefit from Stenting on Cognitive Function in Intracranial Atherosclerosis? Cerebrovasc Dis. 2017; 43 (1-2): 31-5.

33. Tanashyan MM, Medvedev RB, Gemdzhian EG, Skrylev SI, Krotenkova MV, Shchipakin VL, et al. Predictors of acute cerebral embolic lesions during carotid artery stenting. Angiol Sosud Khir. 2019; 25 (4). (In Print)

34. Barber PA, Hach S, Tippett LJ, Ross L, Merry AF. Cerebral ischemic lesions on diffusion-weighted imaging are associated with neurocognitive decline after cardiac surgery. Stroke. 2008; (39): 1427-33. 
1. Танашян М. М., Медведев Р. Б., Евдокименко А. Н., Гемджян Э. Г., Скрылев С. И., Лагода О. В., и др. Прогнозирование ишемических повреждений головного мозга при реконструктивных операциях на внутренних сонных артериях. Ангиология и сосудистая хирургия. 2017; 23 (1): 59-65.

2. Bossema ER, Brand N, Moll FL, Ackerstaff RG, de Haan EH, van Doornen LJ. Cognitive functions in carotid artery disease before endarterectomy. J Clin Exp Neuropsychol. 2006; (28): 357-69.

3. Johnston SC, O'Meara ES, Manolio TA, Lefkowitz D, O'Leary DH, Goldstein S, et al. Cognitive impairment and decline are associated with carotid artery disease in patients without clinically evident cerebrovascular disease. Ann Intern Med. 2004;140 (4): 237-47.

4. Romero JR, Beiser A, Seshadri S, Benjamin EJ, Polak JF, Vasan RS, et al. Carotid artery atherosclerosis, MRI indices of brain ischemia, aging, and cognitive impairment: the Framingham study. Stroke. 2009; 40 (5): 1590-6.

5. Кунцевич Г. И., Танашян М. М., Скрылев С. И., Кротенкова М. В., Щипакин В. Л., Кощеев А. Ю., и др. Интраоперационное мониторирование мозгового кровотока и состояние вещества головного мозга при открытых и эндоваскулярных вмешательствах в каротидной системе. Ангиология и сосудистая хирургия. 2011; 17 (3): 43-8.

6. Barnett HJM, Taylor DW, Haynes RB, Sackett DL, Peerless SJ, Ferguson GG, et al. North American Symptomatic Carotid Endarterectomy Trial Collaborators. Beneficial effect of carotid endarterectomy in symptomatic patients with high grade carotid stenosis. N Engl J Med. 1991; 325 (7): 445-53.

7. Endarterectomy for asymptomatic carotid artery stenosis. Executive Committee for the Asymptomatic Carotid Atherosclerosis Study. JAMA. 1995; 273 (18): 1421

8. Endovascular versus surgical treatment in patients with carotid stenosis in the Carotid and Vertebral Artery Transluminal Angioplasty Study (CAVATAS): a randomised trial. Lancet. 2001; 357 (9270): 1729-37.

9. Mas JL, Trinquart L, Leys D, Albucher JF, Rousseau H, Viguier A, et al. Endarterectomy Versus Angioplasty in Patients with Symptomatic Severe Carotid Stenosis (EVA-3S) trial: results up to 4 years from a randomised, multicentre trial. Lancet Neurol. 2008; 7 (10): 885-92.

10. Brott TG, Hobson RW, Howard G, Roubin GS, Clark WM, Brooks W, et al. Stenting versus endarterectomy for treatment of carotidartery stenosis. N Engl J Med. 2010; 363 (1): 11-23.

11. Медведев Р. Б., Танашян М. М., Скрылев С. И., Гемджян Э. Г., Гулевская Т. С., Ануфриев П. Л. Связь ультразвуковых и морфологических характеристик атеросклеротических бляшек каротидного синуса. Ангиология и сосудистая хирургия. 2018; 24 (4): 43-9.

12. Altinbas A, van Zandvoort MJ, van den Berg E, Jongen LM, Algra A, Moll FL, et al. Cognition after carotid endarterectomy or stenting a randomized comparison. Neurology. 2011; 77 (11): 1084-90.

13. Zhou W, Hitchner E, Gillis K, Sun L, Floyd R, Lane B, et al. Prospective neurocognitive evaluation of patients undergoing carotid interventions. J Vasc Surg. 2012; 56 (6): 1571-8.

14. Barnett HJ, Taylor DW, Eliasziw M, Fox AJ, Ferguson GG, Haynes RB, et al. Benefit of carotid endarterectomy in patients with symptomatic moderate or severe stenosis. North American Symptomatic Carotid Endarterectomy Trial Collaborators. N Engl J Med. 1998; 339 (20): 1415-25.

15. Folstein MF, Folstein SE, McHugh PR. "Mini-mental state". A practical method for grading the cognitive state of patients for the clinician. J Psychiatr Res. 1975; 12 (3): 189-98.

16. Яхно Н. Н. Когнитивные нарушения в неврологической практике. Неврологический журнал. 2006; 11 (1): 4-12.

17. Yadav JS, Wholey MH, Kuntz RE, Fayad P, Katzen BT, Mishkel GJ, et al. Protected carotid-artery stenting versus endarterectomy in high-risk patients. N Engl J Med. 2004; 351 (15): 1493-501.

18. Brott T, Adams HP Jr, Olinger CP, Marler JR, Barsan WG, Biller J, et al. Measurements of acute cerebral infarction: a clinical examination scale. Stroke. 1989; 20 (7): 864-70.
19. Медведев Р. Б., Танашян М. М., Кунцевич Г. И., Лагода О. В., Скрылев С. И., Кротенкова М. В., и др. Ишемические повреждения головного мозга после каротидного стентирования. Ангиология и сосудистая хирургия. 2015; 21 (1): 65-71.

20. Fox HM, Rizzo ND, Gifford S. Psychological observations of patients undergoing mitral surgery; a study of stress. Psychosom Med. 1954; 16 (3): 186-208.

21. Kügler CF, Vlajic P, Funk H, Raithel D, Platt D, et al. The event-related P300 potential approach to cognitive functions of nondemented patients with cerebral and peripheral arteriosclerosis. J Am Geriatr Soc. 1995; 43 (11): 1228-36.

22. Inoue T, Ohwaki K, Tamura A, Tsutsumi K, Saito I, Saito N. Subclinical ischemia verified by somatosensory evoked potential amplitude reduction during carotid endarterectomy: negative effects on cognitive performance clinical article. J Neurosurg. 2013; 118 (5): 1023-9.

23. Xu G, Liu X, Meyer JS, Yin Q, Zhang R. Cognitive performance after carotid angioplasty and stenting with brain protection devices. Neurol Res. 2007; (29): 251-55.

24. Witt K, Borsch K, Daniels C, Walluscheck K, Alfke K. Neuropsychological consequences of endarterectomy and endovascular angioplasty with stent placement for treatment of symptomatic carotid stenosis: a prospective randomised study. J Neurol. 2007; (254): 1524-32.

25. Lal BK, Younes M, Cruz G, Kapadia I, Jamil Z, Pappas PJ. Cognitive changes after surgery vs stenting for carotid artery stenosis. J Vasc Surg. 2011; 54 (3): 691-8.

26. Выборных Д. Э., Федорова С. Ю., Хрущев С. О., Дроков М. Ю., Гемджян Э. Г., Кузьмина Л.А., и др. Когнитивные нарушения у пациентов с заболеваниями системы крови, перенесших трансплантацию аллогенных гемопоэтических стволовых клеток. Обозрение психиатрии и медицинской психологии им. В. М. Бехтерева. 2019; (2): 18-26.

27. Shimada Y, Kobayashi M, Yoshida K, Terasaki K, Fujiwara S, Kubo Y, et al. Reduced Hypoxic Tissue and Cognitive Improvement after Revascularization Surgery for Chronic Cerebral Ischemia. Cerebrovasc Dis. 2019; 47 (1-2): 57-64.

28. List J, Hertel-Zens S, Kübke JC, Lesemann A, Schreiber SJ, Flöel A. Cortical reorganization due to impaired cerebral autoregulation in individuals with occlusive processes of the internal carotid artery. Brain Stimul. 2014; 7 (3): 381-7.

29. Kuo-Lun Huang, Ting-Yu Chang, Meng-Yang Ho, Wei-Hao Chen, Mei-Yu Yeh, Yeu-JhyChang, et al. The correlation of asymmetrical functional connectivity with cognition and reperfusion in carotid stenosis patients. Neuro Image Clinical. 2018; (20): 476-84.

30. Crawley F, Stygall J, Lunn S, Harrison M, Brown MM. Comparison of microembolism detected by transcranial Doppler and neuropsychological sequelae of carotid surgery and percutaneous transluminal angioplasty. Stroke. 2000; (31): 1329-34.

31. Ortega G, Alvarez B, Quintana M, Yugueros X, Alvarez-Sabin J, Matas M. Asymptomatic carotid stenosis and cognitive improvement using transcervical stenting with protective flow reversal technique. Eur J Vasc Endovasc Surg. 2014; 47 (6): 585-92.

32. Turan TN, Smock A, Cotsonis G, Bachman D, Al Kasab S, Lynn MJ, et al. SAMMPRIS Investigators. Is There Benefit from Stenting on Cognitive Function in Intracranial Atherosclerosis? Cerebrovasc Dis. 2017; 43 (1-2): 31-5.

33. Танашян М. М., Медведев Р. Б., Гемджян Э. Г., Скрылев С. И., Кротенкова М. В., Щипакин В. Л., и др. Предикторы острых церебральных эмболических повреждений при стентировании сонной артерии. Ангиология и сосудистая хирургия. 2019; 25 (4). (В печати)

34. Barber PA, Hach S, Tippett LJ, Ross L, Merry AF. Cerebral ischemic lesions on diffusion-weighted imaging are associated with neurocognitive decline after cardiac surgery. Stroke. 2008; (39): 1427-33. 